\title{
Historiadores e cronistas e a paisagem da colônia Brasil ${ }^{1}$
}

Dora Shellard Corrêa

UNIFIEO

\section{RESUMO}

Este artigo discute a paisagem da colônia Brasil no primeiro século da colonização. Analisamos as descrições da paisagem elaboradas por Capistrano de Abreu e aprimoradas por Caio Prado Júnior, as quais ainda são reproduzidas pela historiografia nacional. Comparamos esses quadros com as narrativas feitas por cronistas do século XVI e início do XVII. Objetivamos mostrar através do levantamento de dados sobre as formas indígenas de ocupação e utilização da terra e de seus recursos - os quais conformavam o cenário visualizado e relatado pelos cronistas - que estamos diante de uma zona de fronteira.

Palavras-chave: Paisagem; Brasil colônia; cronistas do século XVI.

\begin{abstract}
This article focuses the Brazilian colonial landscape. We analyze the pattern constructed by Capistrano de Abreu and improved by Caio Prado Júnior that is still a reference to the national historiography, and compare it with the descriptions made by the $16^{\text {th }}$ century chroniclers. Our purpose is to raise facts about the indigenous forms of occupation and use of the land and its resources that outline the scenery visualized by the chroniclers at the first century of the Portuguese colonization. We want to show that the Brazilian coast, at that time, was a frontier zone.

Keywords: Landscape; Colonial Brazil; $16^{\text {th }}$ century chroniclers.
\end{abstract}


Não nos parece possivel negar que uma aldeia de índios, a exemplo de qualquer outro aglomerado de povos primitivos, constituiu um fato geográfico, um dos elementos da paisagem brasileira ... No entanto, em virtude de uma tradição que bem precisa ser revista, tal aspecto não tem merecido as atençães dos geógrafos patrícios, sendo considerado um patrimônio exclusivo da Etnologia ou Antropologia Cultural.

Aroldo de Azevedo, 1959

Várias são as imagens consubstanciadas na memória que conformam nossa visão de mundo e instrumentalizam nossa tomada de decisões - no caso do historiador, nosso olhar sobre a documentação. Uma dessas imagens é a que se refere à existência de uma natureza virgem, de terras desabitadas, vazias da ação humana no Brasil de outrora. Embora muitos já tenham criticado essa visão e apontado o descaso para com as populações indígenas, ela não foi superada. O discurso crítico foi ineficaz na substituição desse cenário por outro mais próximo do real. Ainda nos pautamos sem remendos em Caio Prado Júnior ou em Capistrano de Abreu, criadores desse modelo de descrição da paisagem do Brasil colonial, para descrever o processo de avanço da ocupação portuguesa. Ainda trabalhamos com mapas que expressam pictoricamente essa concepção. Vejam-se, por exemplo, os mapas que Aroldo de Azevedo elaborou no final da década de 1950 para o artigo de Pasquale Petrone, no livro Terra brasileira, ilustrando a marcha do povoamento e da urbanização no Brasil nos séculos XVI, XVII e XVIII. Tais mapas foram republicados em vários outros momentos. Nos anos 70 foram editados na História geral da civilização brasileira, em artigo de Alice Canabrava, e, mais recentemente, os encontramos na obra História do Brasil, de Boris Fausto. Nessas cartas, que têm como base a conformação política do Brasil atual, estão assinaladas as cidades, vilas e áreas sob sua influência, bem como áreas conhecidas e povoadas por colonos, porém sem aglomerados urbanos. O restante do território aparece numa cor única, em geral o branco. Inegavelmente, esse é um material muito interessante para os historiadores, especialmente se tivermos em conta a dificuldade que temos em espacializar os acontecimentos. Entretanto, ao deixar de retratar o que existia no território sobre o qual o povoamento português avançou, reafirma-se o conteúdo dos textos historiográficos que descrevem o sertão como um vazio. Contraditoriamente, Aroldo de Azevedo nos alertou sobre a existência de uma paisagem indígena, desconsiderada por geógrafos em razão de uma tradição que fixa temas de pes- 
quisa de cada ciência e, acrescentaríamos, negada por historiadores em virtude de teorias e ideologias.

Longe de constituírem um detalhe sobre a formação do Brasil, essas imagens segundo as quais Cabral encontrou uma terra em que a paisagem visualizada pouco havia sido transformada pelo homem servem como filtros para a análise da realidade. Se, por um lado, já está mais do que batido que a historiografia brasileira, até recentemente, ignorou os índios como sujeitos na nossa história, por outro, pouquíssimas tentativas foram feitas no sentido de recuperar a memória sobre essas sociedades num espaço concreto. Ao procedermos dessa forma, resumimos a questão indígena, até o início da República, ao genocídio. Desvia-se a atenção da luta pela soberania sobre um espaço (terra, paisagem, recursos naturais) e sobre aqueles que o habitam. Talvez possamos ver nos índios isolados ainda existentes na Amazônia um resquício dessa situação pretérita desprezada. Recuperar as populações indígenas na história significa rediscutir o processo de invasão e ocupação do território brasileiro e do estabelecimento de suas fronteiras.

Os estudos historiográficos impossibilitam concebermos o cenário colonial como algo que vai além das fazendas e das vilas. Além de o sertão ser representado como desabitado, isolam-se paisagisticamente as aldeias e os aldeamentos de índios cristianizados, os quais, não raro, encontravam-se próximo do povoamento colonial e politicamente compunham um mesmo território.

A imagem que temos do Brasil no século XVI é que este possuía pequenos espaços, núcleos com fazendas e vilas formados pela população colonial, pequenos enclaves ambientais e paisagísticos transplantados para o litoral de um continente virgem, embora se saiba que os índios também estavam ali. A matriz desse quadro foi elaborada por Capistrano de Abreu em Caminhos antigos (1924) e depois aprimorada e solidificada por Caio Prado Júnior a partir de Formação do Brasil contemporâneo (1942).

Neste artigo analisamos as descrições da costa brasileira durante o período colonial, elaboradas por Capistrano de Abreu e Caio Prado Júnior, para então revisitar as fontes, os cronistas do século XVI e início do XVII, alguns dos quais utilizados por esses historiadores. Estudou-se Pero Vaz de Caminha (a carta sobre o achamento do Brasil), Hans Staden (Duas viagens ao Brasil), Jean de Léry (Viagem à Terra do Brasil), Pero de Magalhães Gandavo (Tratados da terra do Brasil e História da província de Santa Cruz), Fernão Cardim (Tratados da terra e gente do Brasil), Gabriel Soares de Souza (Trata- 
do descritivo do Brasil em 1587) e Claude D’Abbeville (História da missão dos Padres Capuchinhos na ilha do Maranhão).

Almejamos, com esta pesquisa, iniciar o levantamento de dados para reconstruir nossa memória sobre essa paisagem colonial. Substituir a visão de uma terra virgem por um espaço vivo culturalmente. Pensar a costa brasileira, no século XVI, como uma zona de fronteira, onde convivem formas variadas de ocupação e uso da terra, justapondo-se e se opondo. Este esforço justifica-se pragmaticamente, pois são essas concepções equivocadas sobre a realidade paisagística brasileira pretérita que povoam o imaginário de muitos que têm tomado decisões quanto às políticas relacionadas ao meio ambiente, ao índio e à questão da terra.

\section{A CONSTRUÇÃO DE UM MODELO DE DESCRIÇÃO DA PAISAGEM Colonial: Capistrano de Abreu e Caio Prado Júnior}

No final do século XIX e início do XX, quando se observa a publicação de pesquisas de história metodologicamente mais cuidadas, Capistrano de Abreu edita trabalhos que se transformariam numa referência. Entre outros pontos, o cearense inseriu o espaço geográfico no relato historiográfico. Os historiadores que o seguiram, particularmente aqueles que se debruçaram sobre o Brasil colônia, repetiram suas descrições. Caio Prado Júnior aprimorou aquele modelo em Formação do Brasil contemporâneo, e é até hoje copiado.

Capistrano de Abreu reproduziu em seus retratos da colônia a localização física dos cronistas coloniais, ou seja, descreveu a paisagem como se ele, narrador, estivesse situado na costa, observando o Brasil como alguém que está aportando. Jamais ultrapassou a linha formada pelas terras efetivamente apropriadas, dominadas e povoadas pelos colonos. Além desse território estava o sertão, mas, embora afirme a sua importância para o entendimento da formação do Brasil, jamais o penetra, esboça-o como se estivesse muito longe. Quando busca avançar sobre o sertão, a sua descrição perde objetividade e o que exibe é um cenário caracterizado de forma genérica por seus aspectos geográficos, sugerindo uma natureza virgem.

O historiador cearense descreveu a paisagem colonial e o sertão como uma paisagem natural, virgem, destituída de sinais de interferências humanas, regiões desertas, onde quando muito perambulavam índios. Simultaneamente, contudo, em várias passagens mostrou encontrar-se esse espaço ocu- 
pado por grupos indígenas. Indicou a existência de trilhas, de roças, de aldeias, de sociedades se comunicando.

A crítica a essa construção da imagem de terras desertas no Brasil não é novidade, porém, deixou de ser acompanhada pela reconstrução do cenário. Continua-se a separar a descrição das sociedades indígenas do espaço por elas ocupado e da paisagem constituída. Consolidou-se a imagem de que havia e ainda existem áreas naturais em território hoje brasileiro. Essas representações falsas, parciais da paisagem colonial e do sertão tanto nos convencem que a reproduzimos até hoje. Ignoramos os passos iniciados por Sérgio Buarque de Holanda, o qual, desde a edição de Monções (1945), apresenta um cenário diverso, uma outra visão da fronteira.

A paisagem construída pelos índios, resultado de suas relações com a natureza, é omitida nessa memória já consolidada na historiografia brasileira. O sertão, que fica além do povoamento português, é um espaço natural, natureza virgem, caracterizado pela mata escura, fechada, tropical, pela caatinga, pela zona árida, mas também pelo espaço aberto de difícil trânsito, pelos campos com vegetação rasteira, por rios encachoeirados. Não conseguimos imaginar as sociedades indígenas vivendo, produzindo, comunicando-se, movimentando-se nesse espaço. Embora os dados mostrem a existência de aldeias de razoável extensão, trilhas indígenas e uma resistência bem aguerrida de muitos grupos, tais fatos não interferem na característica natural da paisagem. Conforme Capistrano de Abreu e, principalmente, depois de Formação do Brasil contemporâneo, os índios se escondem nas matas, vivem errantes, isolados em pequenos grupos, e poucas marcas deixam de sua existência.

Enfim, podemos enumerar outras questões metodológicas, porém aspectos políticos e ideológicos interferem fortemente na construção dessas paisagens. Para Capistrano de Abreu os índios eram racialmente inferiores aos europeus e não chegaram a ter influência na formação do Brasil. Daí a desconsideração com relação às sociedades indígenas e à paisagem que construíram.

Em Formação do Brasil contemporâneo, Caio Prado Júnior segue Capistrano de Abreu ao descrever o povoamento do Brasil desde o século XVI até o início do XIX. Se metodologicamente e politicamente vemos propostas antagônicas, os dois historiadores aproximam-se quanto a sua concepção sobre o que é importante acentuar na descrição do cenário: a área colonizada pelos portugueses. Dentro desta, priorizou-se a recuperação das vilas, fazendas, produção e estradas. Desprezaram-se os territórios indígenas, seus sítios, suas roças e caminhos e, mesmo, as aldeias vizinhas às vilas coloniais. 
No seu primeiro capítulo de Formação do Brasil contemporâneo, em que traçou o povoamento português no território americano, Caio Prado desconsiderou as transformações processadas naquela paisagem. Uma descrição interessante, porém ancorada em dados do século XIX, numa projeção pretérita desse século, como se o que conformou aquele cenário foi somente a interferência ocidental e uma dinâmica natural. O historiador paulista considerava os índios como totalmente incapazes de adequarem o meio natural à sua cultura e à sua vida material. Segundo ele, a mata era o esconderijo dos índios que fugiram ao avanço português. Partia do pressuposto segundo o qual os índios pouco interferiam no meio natural, uma vez que os portugueses, ao chegarem, encontraram um ambiente semivirgem. O grande empecilho aos intentos coloniais foram os acidentes geográficos. Para ele, "É o comércio que os interessa, e daí o relativo desprezo por este território primitivo e vazio que é a América”. ${ }^{2}$ Dessa forma, procurou na geografia os dados sobre a costa brasileira e os projetou para os séculos XVI, XVII, XVIII e XIX.

Caio Prado Júnior reproduziu o local a partir do qual a maior parte dos cronistas, especialmente aqueles que estavam atentos às condições de exploração dos recursos naturais desse território em benefício da Metrópole, descreviam aquelas terras. Posicionou-se no mar, como se estivesse percorrendo a costa numa embarcação. No leitor, provocou a sensação de que a vida, a história e o movimento transformador emanavam dos estabelecimentos europeus. Que o resto do território que viria a ser o Brasil, ocupado por sociedades tribais, estava isolado numa dinâmica a-histórica e natural. A descrição de Caio Prado Júnior afirma um vazio humano/cultural que é falso.

Vários são os fatores que explicam e dão força a essas imagens. Num primeiro momento, a separação entre a descrição geográfica e as formas de ocupação indígena. Aliada a esse fato, temos a homogeneização das sociedades indígenas, ou seja, a eliminação da diversidade de culturas, formas de ocupação e de transformação do espaço. No primeiro capítulo do livro Capítulos de história colonial, intitulado "Antecedentes indígenas", Capistrano de Abreu exemplifica essa afirmação. Dois terços dele são dedicados à descrição da paisagem, flora e fauna da costa brasileira. O restante apresenta uma generalização da organização política e social indígena, apesar de se reconhecer que eram muitas e diversificadas essas sociedades.

Outro elemento que reforça essas imagens é que Capistrano projetou a realidade de seu presente, início do século XX, para os séculos passados. Embora mostrasse que muitos grupos indígenas resistiram até se retirarem mais para o interior do continente, quando não foram totalmente dizimados, des- 
prezou os indícios de sua ocupação. Chega até a fornecer informações sobre migrações pré-cabralinas, embora leve a crer que nada sobrou dessa transumância no espaço.

Capistrano de Abreu e Caio Prado Júnior utilizam predominantemente fontes do século XIX. Já haviam se passado mais de trezentos anos de ocupação portuguesa, de confrontos e contatos entre índios e colonos, metrópole e nações indígenas, de imigração africana. Já haviam transcorrido mais de trezentos anos de uma história da qual possuímos poucos fragmentos, determinada pela dinâmica própria das sociedades indígenas naquele território. Além disso, esses viajantes de onde os historiadores recuperam a paisagem colonial, por questões metodológicas que se impõem até hoje, separavam a descrição da natureza das formas de ocupação humana. Levando-se em consideração que Capistrano de Abreu e Caio Prado Júnior tinham conhecimento desses textos, a sua descrição de uma zona litorânea com abundância de matas, sem nenhuma referência às aldeias indígenas, só pode ser explicado por opções teórico-metodológicas, um tanto quanto ortodoxas, que os levaram a desconsiderar conscientemente tais dados. Estes são muito claros.

Capistrano de Abreu e Caio Prado Júnior, apesar de metodologicamente e teoricamente, portanto politicamente, apresentarem visões antagônicas, suas descrições da paisagem colonial se aproximam. Comungam, por questões diversas, a incapacidade dos índios em transformarem a natureza, em serem sujeitos da história, seja por sua inferioridade racial seja por encontrarem-se num estágio defasado de evolução sócio-econômica. Tais pressupostos levaram a que as suas leituras da documentação, quanto ao que eram essas terras em termos paisagísticos no período colonial, fossem semelhantes. Consciente ou inconscientemente obscureceram a ação indígena. Ocultaram dessa paisagem a exposição das aldeias e a interferência indígena na natureza, embora tivessem informações para construir outro quadro. Os cronistas coloniais expuseram esses dados.

\section{A PAISAGEM DA COSTA ATLÂNTICA DA AMÉRICA CONFORME OS CRONISTAS DO SÉCULO XVI}

Os relatos dos cronistas do século XVI e início do XVII confirmam, como veremos, a omissão sobre a paisagem construída pelos índios. Entretanto, para utilizarmos seus dados, há que proceder-se à crítica. Afinal, devemos ter em conta a situação do narrador, alguém que efetivamente freqüentou os lo- 
cais que está descrevendo, ou que os visualizou de longe, ou que os descreveu a partir de informações fornecidas por outra pessoa. Porém, devemos lembrar que nenhum desses cronistas, excetuando Pero Vaz de Caminha, escreveu seu texto imediatamente após o acontecimento narrado. Todos os relatos foram feitos a posteriori, após um ano no mínimo. Resultam de memórias. Às vezes percebemos que o dado escrito não passa de uma transcrição de outro cronista.

Para definir o grau de objetividade dessas descrições quanto aos intentos desta pesquisa, estipularam-se alguns critérios. Num primeiro momento, atentou-se para a posição do narrador. Assinalou-se o fato de ser um participante direto do que narrava ou um transmissor de experiências e realidades visualizadas por outros colonos. Posteriormente, questionou-se o objetivo último do texto: uma exposição tendo em vista estimular ou avaliar as condições de povoamento da colônia, um relatório fruto de exigência rotineira de um cargo ou de uma posição, um texto voltado para a oficialização de uma notícia, ou, finalmente, uma memória escrita e publicada para expor uma experiência incomum, uma aventura, enfim um diário de viagem.

Pero Vaz de Caminha era escrivão da armada de Pedro Álvares de Cabral em 1500, quando conheceu o que viria a ser a colônia portuguesa na América. A carta que escreveu na ocasião tinha como objetivo informar o rei D. Manuel I sobre o achamento das terras e narrar-lhe o que aí haviam encontrado. Esse documento foi publicado em livro somente em 1817.

Hans Staden, natural de Hesse, Prússia, era um aventureiro. Frente ao insucesso de sua tentativa de embarcar para a Índia, viajou para o Brasil empregando-se como artilheiro numa nau que partiu de Lisboa. Visitou por duas vezes a colônia portuguesa. Primeiro em 1547, demorou-se por volta de dezenove meses. Sua segunda estadia foi mais longa. Aportou em 1550, permanecendo cinco anos na América, dos quais, nos últimos nove meses, foi prisioneiro de um grupo Tupinambá. ${ }^{3}$ De volta à Prússia em 1555, publicou no ano seguinte as suas memórias sobre essas duas viagens à colônia portuguesa, retratando particularmente sua experiência entre os índios.

Jean de Léry era francês, sapateiro e estudioso de teologia. Embarcou para o Brasil com outros artesãos a fim de participar da tentativa de colonização francesa no Rio de Janeiro, a França Antártica. Chegou a março de 1557 e partiu em janeiro de 1558. Em seu livro descreve o estado da colônia francesa, os aspectos geográficos das áreas que visitou, a fauna, a flora e os costumes indígenas e aldeias que conheceu. Seu objetivo, com a publicação das memórias, era informar sobre a malograda experiência colonizadora francesa na 
América do Sul. Publicou seu livro somente em 1577, dezoito anos após ter estado no Brasil. Porém, o primeiro relato, que já estava pronto em 1563, foi perdido. Reescreveu outro texto a partir de suas anotações.

Pero Magalhães Gandavo, português, residiu algum tempo no Brasil, porém não se sabe quanto e nem se visitou pessoalmente toda a colônia, como seus dois livros pressupõem. Acredita-se, dado o maior detalhamento das capitanias da Bahia, Ilhéus e São Vicente, que as conheceu pessoalmente. Escreveu dois livros: Tratado descritivo e História da Província de Santa Cruz a que vulgarmente chamam de Brasil. Foram publicados em épocas diversas, o último ainda em 1575 e o Tratado somente no século XIX. Em ambos descreveu os aspectos geográficos, a fauna e a flora da colônia lusa, os costumes indígenas e as povoações coloniais.

Dedicando seus livros a políticos importantes da metrópole, Gandavo escreveu que seu objetivo era difundir em Portugal informações sobre as riquezas naturais e as vantagens da colonização do Brasil procurando, dessa forma, animar aqueles que podiam imigrar.

O jesuíta Fernão Cardim era português. Chegou ao Brasil em 1584, com a incumbência de acompanhar o padre visitador, Cristóvão de Gouvêa, em seu reconhecimento das ações e obras desenvolvidas pela ordem na colônia lusa. Morreu na Bahia em 1625. No transcurso desses quarenta e um anos assumiu vários cargos religiosos na colônia, entre eles o de reitor do colégio da Companhia de Jesus no Rio de Janeiro. O seu livro é composto por três tratados: Narrativa epistolar de uma viagem e missão jesuítica pela Bahia, Ilhéus, Porto Seguro, Espírito Santo, Rio de Janeiro, São Vicente etc., desde o ano de 1583 ao de 1590; Do princípio e origem dos índios do Brasil e de seus costumes, adoração e cerimônias (possivelmente do último quartel do século XVI); Do clima e terra do Brasil e de algumas coisas notáveis que se acham assim na terra como no mar (1590). O objetivo de suas narrativas era relatar à Companhia de Jesus as ações dos jesuítas na colônia e descrevê-la aos demais representantes da ordem.

Gabriel Soares de Souza, de origem portuguesa, foi senhor de engenho na Bahia, onde viveu por volta de vinte e quatro anos. Morreu numa entrada que fez ao sertão das Minas Gerais. Em Tratado Descritivo do Brasil, de 1587, apresentou um roteiro geral da costa brasileira, do Amazonas ao rio da Prata, retratando a geografia, a flora, a fauna, as povoações coloniais e as populações indígenas. Na segunda parte da obra fez um memorial sobre a Bahia. O texto foi escrito em 1587, na Europa, quando buscava receber favores e honrarias, além da autorização para uma expedição para o sertão. Exaltou as qua- 
lidades positivas da colônia e defendeu um maior empenho das autoridades metropolitanas com a colonização do Brasil, em razão das perspectivas positivas que a exploração daquelas terras apresentava.

A narrativa é resultado das observações pessoais de Gabriel Soares de Souza. Contudo, o sesmeiro incorporou também informações extraídas de outras crônicas e de outros colonos. Várias passagens de seu livro aproximam-se muito do relato de Pero Magalhães Gandavo, comprovando sua leitura prévia.

Claude d'Abbeville, capuchinho francês, permaneceu por quatro meses, em 1612, no Maranhão, então em posse dos franceses. Seu livro relata a história de sua missão, da saída da Europa à chegada ao Brasil, do que viu no Maranhão, dos colonos, índios e suas aldeias, da terra, clima, flora e fauna. Publicou seu livro em 1614, após seu retorno à França.

Todas essas crônicas foram escritas no século XVI, excetuando-se a de Claude d'Abbeville, do início do século XVII. Resultaram de experiências acontecidas na colônia portuguesa, embora um ou outro autor tenha incorporado dados retirados de observação alheia. Contudo, apesar das semelhanças, distanciam-se quanto aos seus intentos. Hans Staden, Jean de Léry e Claude d'Abbeville produziram relatos sobre suas aventuras e desventuras no Brasil. Pero Magalhães Gandavo e Gabriel Soares de Souza preocuparam-se em propalar as qualidades das terras brasílicas para as autoridades e aqueles propensos a imigrar para a América. Padre Fernão Cardim dividia com os demais representantes da Companhia de Jesus as informações sobre as ações empreendidas pelos jesuítas na colônia e buscava inteirá-los sobre essas terras e seus habitantes. De todos esses europeus, Hans Staden foi o único que conviveu com os índios e perambulou por território indígena, observando e registrando a vida no sertão.

As descrições desses cronistas estão longe de seguir rigorosamente um mesmo modelo. A idéia de que as narrativas são homogêneas ou equivalentes e que podemos generalizar a informação contida num texto para as demais, é questionável em determinadas situações. A reprodução pura e simples de seus dados nos leva a uma falsa imagem, caso não tenhamos em conta o objetivo da observação que define o visualizado e memorizado pelo cronista. De maneira alguma estamos negando que a visão de mundo, que filtra a relação entre o real e o visualizado e que determina o que se apresenta passível de ser concebido por esses narradores, é um fato social. Porém, devemos levar em conta que os cronistas descreveram a partir de dados locais concretos e que tinham intentos singulares publicando os seus relatos. Tais situações, aliadas à sua visão de mundo, conformaram os textos. 
Esses cronistas observaram a terra e seus habitantes a partir de ângulos físicos diversos. Alguns caminharam com os índios, outros atravessaram aldeias submetidas, outros miraram do mar, outros nem viram muitas coisas que relataram. Staden localizou as aldeias Tupinambá entre Bertioga e Rio de Janeiro, Léry mencionou todas que ficavam ao redor do Rio de Janeiro, Cardim situou os aldeamentos jesuíticos da Bahia a São Paulo, Gabriel Soares de Souza posicionou os grupos indígenas que caracterizou num espaço aparentemente livre para a ocupação européia.

A carta de Pero Vaz de Caminha é um dos primeiros documentos expondo como eram as terras e os povos contatados pelos portugueses na América, em 1500. Nesse texto encontramos informações que seriam repetidas por boa parte desses cronistas do século XVI. A saber, os bons ares, a infinidade de águas e a riqueza da terra onde dar-se-á tudo: "Porém a terra em si é de muito bons ares, assim frios e temperados ... Águas são muitas; infindas. E em tal maneira é graciosa que, querendo-a aproveitar, dar-se-á nela tudo, por bem das águas que tem". ${ }^{4}$ Segundo Sérgio Buarque de Holanda, pode-se ver aí a reprodução de estruturas descritivas expostas em textos religiosos.

O escrivão estava mais atento aos índios que à paisagem, embora não tenha deixado de esboçá-la. Iniciou, contudo uma prática que se impôs até a atualidade, a descrição em separado dos índios e de suas aldeias, do cenário natural — das matas, dos bichos e dos rios - como se fossem espaços desconexos.

Caminha inicia sua carta ao Rei D. Manuel I relatando o que avistava panoramicamente do mar: "Houvemos vista da terra! Primeiramente dum grande monte, mui alto e redondo; e doutras serras mais baixas ao sul dele; e de terra chã, com grandes arvoredos: ao monte alto o capitão pôs o nome - o Monte Pascoal e à terra - Terra da Vera Cruz". ${ }^{5}$ Ao ancorarem no dia seguinte, avistaram alguns índios na praia. Daí para frente, a atenção eram os índios e suas movimentações, suas habitações e seu aspecto físico. Somente ao final do texto Caminha faz uma descrição mais completa do cenário, porém apenas da paisagem natural:

Esta terra, Senhor, me parece que da ponta que mais contra o sul vimos até outra ponta que contra o norte vem, de que nós deste porto houvemos vista, será tamanha que haverá nela bem vinte ou vinte e cinco léguas por costa. Tem, ao longo do mar, nalgumas partes, grandes barreiras, delas vermelhas, delas brancas; a terra por cima toda chã e muito cheia de grandes arvoredos ... Pelo sertão 
nos pareceu, vista do mar, muito grande, porque, a estender olhos, não podíamos ver senão terra com arvoredos, que nos parecia muito longa. ${ }^{6}$

Caminha negligencia os indícios de existência humana naquele ambiente, ainda que, ao longo do tempo em que permaneceram na costa, jamais tenham deixado de estar acompanhados atentamente pelos habitantes da região.

Informa que as povoações indígenas ficavam mais recuadas no sertão, pois para lá se encaminharam os dois degredados que Cabral mandou acompanhar os índios e pernoitar com eles. Transcrevendo a exposição de Afonso Ribeiro e dois outros degredados que seguiram até a aldeia, conta:

foram bem uma légua e meia a uma povoação, em que haveria nove ou dez casas, as quais eram tão compridas, cada uma, como esta nau capitânia. Eram de madeira, e das ilhargas de tábuas, e cobertas de palha, de razoada altura; todas duma só peça, sem nenhum repartimento, tinham dentro muitos esteios; e, de esteio a esteio, uma rede atada pelos cabos, alta, em que dormiam. Debaixo, para se aquentarem, faziam seus fogos. E tinha cada casa duas portas pequenas, uma num cabo, e outra no outro.?

Aparentemente deixaram de ver roças, pois Caminha escreveu que os índios não plantavam, nem criavam animais.

Dormirem na aldeia, familiarizarem-se mais com os indígenas e dessa forma conhecer mais a terra eram as incumbências dos degradados. Entretanto, na primeira tentativa de acompanharem os índios, foram impedidos e enviados de volta à praia. Ainda que Caminha percebesse o fato de evitarem que os portugueses pernoitassem na aldeia, de muitos se esconderem na mata enquanto outros se mostravam e de, em geral, portarem seus arcos e flechas, afirmou a ingenuidade dos índios e sua confiança perante os portugueses.

A carta de Caminha sugere que os portugueses, antes da chegada da esquadra de Pedro Álvares Cabral, já haviam estabelecido contato com os povos que habitavam aquela parte da costa baiana. No primeiro encontro a troca de arcos e flechas, de sombreiro de penas de aves e miçangas de continhas brancas por carapuças de linho e barretes vermelhos (coberturas para a cabeça) sugere uma prática já reconhecida por ambos, assim como o sinal para que descansassem suas armas no chão. A atenção de Caminha para a quantidade de índios que os recepcionava, sempre variável, e a indicação sobre o porte de armas - somente num dos encontros os índios não as carregaram —, revela a desconfiança e a constante vigília de ambos os lados. 
Caminha esclareceu, logo ao início da carta, que, como os capitães, forneceria somente as notícias das terras achadas. O caminho, afirma ele, não cabia ele contar, era responsabilidade dos pilotos. Ressaltou que só falaria sobre o que visualizara. Dado que a carta indica que os portugueses já haviam estabelecido anteriormente contatos com os índios e, portanto, aportado naquele litoral, o escrivão não foi o primeiro a revelar as terras e suas gentes. Sua descrição sugere que seu objetivo, ao observar o cenário, era sublinhar as qualidades positivas daquela região quanto aos intentos lusos. Sobre os índios, sua real apreensão, pareceu estar avaliando-os enquanto possíveis colaboradores ou empecilhos às ações portuguesas. Cabe apontar que, nesse suposto primeiro contato, Cabral partiu com carregamento de madeiras. A inexistência de ferramentas de ferro, úteis no corte de madeira, é acentuada pelo escrivão. O ferro foi uma das principais mercadorias comercializadas com os indígenas no século XVI. Nesse contexto, a separação que Pero Vaz de Caminha fixou entre a descrição da paisagem e a dos homens é lógica, uma vez que sua preocupação consistia em fornecer dados objetivos que auxiliassem numa empresa que já estava definida, a exploração daquelas terras.

As duas outras cartas que relatam a chegada de Cabral à América, a do Mestre João Faras e a do Piloto Anônimo, são mais pobres de observações sobre as terras americanas. $\mathrm{O}$ primeiro nada escreve sobre o achado. $\mathrm{O}$ segundo repete alguns dados fornecidos por Caminha sobre o aspecto físico dos índios, suas moradias e o fato de não terem instrumentos de ferro e cortarem árvores com machados de pedra.

As aventuras de Hans Staden apresentam-se como as mais interessantes para este artigo, pois foi ele o único que viveu entre os índios e os acompanhou em seu cotidiano. O relato que fez sobre o que viu, particularmente quando prisioneiro dos índios, destaca-se frente às outras crônicas porque se refere a dados e acontecimentos desenrolados no interior de território indígena. Assim, vamos utilizar o seu texto e os temas por ele elencados como base para a discussão a seguir.

Hans Staden viveu ao longo de nove meses, entre 1554 e 1555, numa aldeia Tupinambá, localizada aproximadamente a 30 milhas de Bertioga. Levaram três dias para percorrê-las. Acredita Francisco de Assis Barbosa ${ }^{8}$ que essa aldeia, denominada Ubatuba, encontrava-se na enseada de Mangaratiba, no atual estado do Rio de Janeiro. Compunha-se de cinco grandes tabas, feitas em barro e palha, e era cercada por paliçadas denominadas caiçaras: "fortificação de estacas longas e grossas que rodeia suas choupanas como a cerca dum jardim". ${ }^{9}$ Essa povoação seguia o padrão das demais que o alemão co- 
nheceu, as quais contavam com até sete cabanas cercadas, e situavam-se perto de água, caça e pesca.

Claude d'Abbeville, retratando as aldeias tupinambá da ilha do Maranhão, em 1611, alerta que divergiam do que um europeu estava familiarizado a ver em seu continente:

Em primeiro lugar cabe observar que essas aldeias não são como as nossas, e menos ainda se parecem com cidades bem edificadas, cercadas de baluartes ou trincheiras, ou ainda de fossos, com ricos palácios, belas residências e castelos inexpugnáveis. Suas aldeias, a que chamam Oc ou Taba, não passam de quatro cabanas feitas de paus grossos ou estacas e cobertas de cima a baixo com folhas de palmeira a que denominam Pindó, encontrável em grande abundância nas matas ... As casas têm de vinte e seis a trinta pés de largura e de duzentos a quinhentos pés de comprimento, segundo o número de pessoas que nelas habitam. São construídas em forma de claustro, ou melhor, em quadrado como o Place Royale, de Paris, de modo que há sempre entre elas uma praça grande e bonita. As quatro casas assim dispostas, com a praça ao centro, formam uma aldeia. ${ }^{10}$

O capuchinho francês continua descrevendo cada uma dessas povoações, Itapari, Carnaupió, Timboí Euaíve, Itaendave, Araçuí-Jeuve e as outras localizadas na ilha e no continente, ao todo reconheceu 47 povoados indígenas em terras invadidas pelos súditos da França. Uns cinqüenta anos antes, um outro francês, o protestante Jean de Léry, visitara 22 aldeias Tupinambá no Rio de Janeiro, nas proximidades da baía da Guanabara. Embora menores, mais rústicas e mais frágeis que os povoados europeus, eram percebidos facilmente pelos cronistas como algo que caracterizava o cenário, que compunha a paisagem.

Conforme Claude d'Abbeville, os Tupinambá do Maranhão habitavam as matas adjacentes à praia, próximos à pesca e também à água doce. Ao encontrarem um lugar adequado punham fogo à mata para limpar o terreno e depois construíam as cabanas bem no centro dessa clareira. Permaneciam por volta de cinco anos, queimando-a posteriormente. Nada informa se esses povoados, destruídos e abandonados, espaços tomados da floresta, eram reutilizados. Pasquale Petrone, em Aldeamentos paulistas, acredita que os colonos portugueses tenham recolonizado algumas dessas áreas, como foi o caso no planalto paulistano.

Hans Staden também localizou a roça, além da área ocupada pela aldeia Tupinambá onde ficou aprisionado. Próximo à povoação, porém fora da caiça- 
ra, as mulheres semeavam mandioca em momentos determinados pelas estações. Descreveu suas técnicas de limpeza do terreno e plantio. Quando queriam plantar derrubavam as árvores do lugar escolhido e deixavam-nas secar por cerca de três meses. Queimavam-nas então. Depois plantavam a mandioca.

A aldeia de Ubatuba localizava-se próximo à praia, tanto que, ao longo do caminho de Bertioga à enseada de Mangaratiba, os Tupinambá remaram pelo mar. Ao se aproximar, Staden visualizou a aldeia da costa, assim como a roça onde as mulheres lavravam: "Quando nos aproximamos, vimos uma pequena aldeia de sete choças. Chamavam-na Ubatuba. Dirigimo-nos para uma praia, aberta ao mar. Bem perto trabalhavam as mulheres numa cultura de plantas de raízes, que eles chamam de mandioca ... Fomos à terra". ${ }^{11}$ Essa descrição de Hans Staden escrita mais de um ano após o fato ocorrido, portanto, determinada pela memória e pelo interesse em entreter o seu leitor, pode ter sido maquiada. Entretanto, a proximidade da aldeia em relação à praia é reproduzida em relatos de outros cronistas. Os índios que recepcionaram a esquadra de Cabral viviam perto do mar, tanto que, ao final do dia, degredados eram enviados para pernoitar em suas moradias. Entretanto, retornavam no mesmo dia, ao anoitecer, porque não se queria eles ali. Nada indica que tivessem caminhado muito para chegar lá. Jean de Léry informa que quando o navio francês em que viajava aportou em Cabo Frio, um porto muito visitado pelos franceses, deu tiros de canhão para avisar aos habitantes que estavam chegando. Logo os índios surgiram na costa, o que indica estarem próximos. Em sua primeira viagem ao Brasil, em 1549, Hans Staden, navegando defronte à ilha de Santa Catarina, enxergou, em frente da floresta, num vale, algumas choças abandonadas. Enfim, diferentemente do que sugerem as descrições de Capistrano de Abreu e de Caio Prado Júnior e questionando a afirmação de Aroldo de Azevedo, em "Aldeias e aldeamentos", publicado no Boletim Paulista de Geografia n.33, de que as aldeias, no século XVI, não apareciam na praia em contato com o mar, percebe-se que algumas estavam bem próximas, a ponto de serem visualizadas do mar, ou encontravam-se a uma distância desnecessária de ser calculada. 


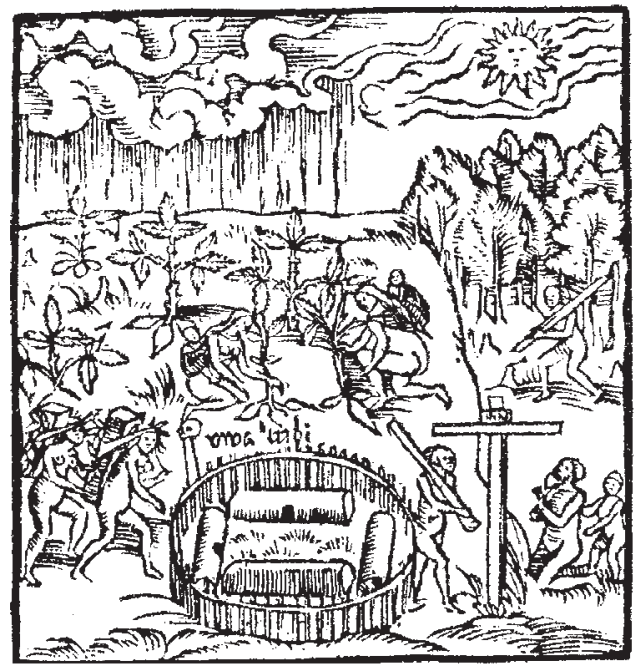

Figura 1 - A aldeia de Ubatuba, onde Hans Staden permaneceu prisioneiro.

Fonte: STADEN, Hans, p.135. Este desenho, ao que parece elaborado por Hans Staden e publicado em seu livro, reproduz a aldeia de Ubatuba. Em praticamente todas as figuras de sua obra ele está inserido como um personagem da cena. Acima o vemos rezando próximo à cruz.

A Ubatuba em que viveu Staden encontrava-se possivelmente numa clareira expressiva, tanto que ele consegue da praia ver a aldeia e a roça fora das paliçadas que circundavam as tabas. Concebia a mata como um espaço desincorporado ao da aldeia. A integração dos dois espaços, de moradia e de caça, é demonstrada pela referência à forma de sobrevivência cotidiana dos Tupinambá - entravam na mata para caçar. Mas é ilusório ver a mata como a contraparte da aldeia em termos culturais, o espaço da inexistência de intervenção humana, seja ideológica, seja material. Devemos lembrar que os sertanistas reconheciam os territórios indígenas por detalhes imperceptíveis aos desacostumados à vida no sertão. Às vezes identificavam terras de amigos ou de inimigos pela forma como o mel havia sido extraído de uma abelheira, como nos informa Sérgio Buarque de Holanda em Caminhos e fronteiras.

Durante sua estadia com os Tupinambá, Hans Staden foi levado para várias outras aldeias próximas daquela em que morava. Essa vizinhança dos demais povoados significa a existência de uma área dominada por eles, que visivelmente o alemão identifica: 
Os Tupinambás habitam defronte da citada grande serra, bem junto ao mar; mas também além da montanha se estende o seu território por cerca de sessenta milhas. No rio Paraíba, que nasce nesta serra e corre paralelo à costa, desembocando então no mar, têm eles também terra, que habitam, beirando uma região de vinte e oito milhas de comprimento. ${ }^{12}$

A idéia de que existem territórios étnicos é marcada também pelo mapa que desenha e publica ao final de seu livro, localizando e denominando os vários territórios indígenas ao longo do litoral do Maranhão ao rio da Prata. Indica a terra dos Carijó, dos Tupiniquim, dos Martacaiá, dos Carajá e dos Potiguara, e onde moravam os Guaianá. Fernão Cardim também fez a mesma referência, enumerando grupos indígenas e a região ocupada por eles: "Vizinho aos Tupinaquins habitão os Guaimurês, e tomão algumas ouitente léguas de costa, e para o sertão quando querem, são senhores dos matos selvagens". Os Aenaguig: "foram moradores de terras dos Tupiniquins, e porque os Tupiniquins focarão senhores das terras". "Outros que chamão Quirigmã, estes forão, senhores das terra da Bahia e por isso se chama a Bahia Quigrigmurê”. ${ }^{13}$ Porém, essas são narrativas que expressam uma concepção européia sobre organização e domínio espacial. Os cronistas decodificaram dessa forma o que viram na colônia. Torna-se difícil inferir sobre a consciência da realidade de um território étnico por parte dos índios.

Em Pero Magalhães Gandavo há referência semelhante, ou seja, da consciência entre os colonos sobre a existência de um território índio a ser dominado. O português indica outro fato, que entre as povoações dos colonos permaneceram aldeias indígenas, mostrando que o cenário das terras ditas colonizadas era também diverso daquele que em geral a historiografia pinta — cidades, vilas e fazendas isoladas em meio a uma natureza virgem. A paisagem era muito mais diversificada culturalmente do que se percebe nessa generalização.

Era grande a movimentação dos índios pela costa atlântica, percorrendo distâncias expressivas. No relato de Hans Staden o vemos viajando com os da aldeia de Ubatuba três a quatro dias para atacarem um inimigo tradicional, os Tupiniquim, ou para visitarem outros Tupinambá. As guerras aos povos inimigos eram freqüentes, definidas pelo ciclo da natureza. Conforme conta o alemão:

Por volta de 14 de agosto de 1554 iniciamos esta expedição guerreira. Vem neste mês, como já se narrou, do mar para as correntes de água doce, para aí de- 
sovar, uma espécie de peixes. Em português chamam-nos tainhas; em espanhol, lisas, e na língua dos nativos, piratís. Os índios chamam piracema a este tempo de desova. Nesta época partem eles todos para a guerra, tanto os tupinambás como os seus inimigos, e durante a marcha apanham e comem os peixes. Retardam-se na ida; na volta, porém, viajam o mais depressa que podem. ${ }^{14}$

Os Tupinambá estavam sempre informados sobre as outras aldeias e regiões. Hans Staden não esclarece como as notícias eram transmitidas, mas indica sua circulação. Os Tupiniquim assaltaram a aldeia onde o alemão estava preso. Frente ao insucesso da empresa, investiram contra outro povoado Tupinambá, Mambucaba, localizado proximamente. Os de Ubatuba ao ficarem sabendo do acontecido, correram em auxílio:

No dia seguinte veio a notícia de que os tupiniquins, após sua retirada de Ubatuba, onde eu me achava aprisionado, tinham assaltado a aldeia de Mambucaba. Os habitantes haviam fugido, salvo um menino pequeno, que foi feito prisioneiro. As cabanas foram reduzidas a cinzas ... Nhaêpepô-oaçú transportou-se para lá, pois eram seus parentes e amigos, e queria ajudas aos habitantes a reerguer suas choças. ${ }^{15}$

As constantes visitas às diversas aldeias Tupinambá, a marcha para as guerras que pareciam rotineiras e a circulação de informações sobre os acontecimentos de outros povoados expõem uma intensa movimentação dentro e fora do sertão. Direções certas, pousos já testados e utilizados revelam, além da agitação, a existência de caminhos, direções e rumos conhecidos e costumeiros.

Numa descrição geral do território Tupinambá, Hans Staden indicou que habitavam em frente à serra do Mar, bem junto à praia. Ao que parece o arcabuzeiro recuperou esses dados através de informantes, pois não há nada que sugira que ele, ao longo dos nove meses passados com os índios, tenha se distanciado da costa, ou escalado a serra do mar. Demonstra, contudo, que a autonomia política de cada núcleo, da aldeia, está longe de resultar em isolamento e em inexistência de uma identidade cultural.

Os cronistas expuseram parcialmente cenários definidos pelo viver das sociedades indígenas. Reconheceram a sua soberania sobre essas terras, tanto que identificaram seus sinais na paisagem. Revelaram espaços movimentados pela circulação dos índios, de informações, de presentes (Hans Staden foi dado de presente por seu senhor de Ubatuba, Ipiru-Guaçu, a um Tupinambá de 
Taquaraçu-tiba) e de mercadorias (os Tupinambá comerciavam com os franceses, os Tupiniquim com os portugueses), bem como por guerras.

Evidenciaram que as sociedades indígenas tinham uma dinâmica no continente, uma história, que a chegada dos europeus não interrompeu; pelo contrário, num primeiro momento os colonos e a metrópole assimilaram-se a ela. Gabriel Soares de Souza discorrendo sobre a costa de Ilhéus indicou que os Aimoré haviam levado os Tupiniquim a migrarem para outra região:

Parece razão que não passemos avante sem declarar que gentio é este a quem chamam aimorés, que tanto dano tem feito a esta capitania dos Ilhéus, segundo fica dito, cuja costa era povoada dos tupiniquins, os quais a despovoaram com medo destes brutos, e se foram viver ao sertão. ${ }^{16}$

Fernão Cardim sublinhou que toda uma parte do litoral baiano estava se despovoando de colonos por causa dos Tapuya: "Estes dão muito trabalho em Porto Seguro, Ilhéos e Camamu, e estas terras vão despovoando por sua causa". ${ }^{17}$

Os portugueses, no seu primeiro século de colonização, apesar de seus objetivos mercantilistas e da posse daquelas terras, integraram-se parcialmente, quando aportaram na América, à sua dinâmica histórica pretérita. Na memória recuperada pelos cronistas, havia um afluxo de grupos indígenas que habitavam a costa rumo ao interior, em função de lutas tradicionais. Portugueses e franceses participaram dessas rixas, inseriram-se nessa história. Hans Staden revelou que a união entre Tupinambá e franceses fazia parte de uma estratégia político-militar e comercial. Os Tupinambá desgostavam dos portugueses e eram inimigos históricos dos Tupiniquim, amigos dos lusos. Mas sua relação com os franceses não se resumia a essa questão, também era definida por relações comerciais, pois queriam ferro, machados e anzóis especialmente, em troca do que forneciam penas, couros e madeiras. Foi a historiografia que criou a ilusão de que os estrangeiros tivessem uma consciência maior que a dos índios, sobre o que estava em xeque ali, o domínio do espaço e dos recursos naturais. Tal perspectiva é negada pela leitura de Hans Staden, Fernão Cardim, Pero Magalhães Gandavo e Gabriel Soares de Souza.

Algumas aldeias indígenas foram localizadas pelos cronistas adjacentes a fazendas e a vilas coloniais. Gabriel Soares de Souza, depois de comentar a migração dos Tupiniquim para o sertão, expôs que os poucos que permaneceram habitavam vizinhos a engenhos: "dos quais tupiniquins não há já nesta capitania senão duas aldeias, que estão juntos dos engenhos de Henrique Luís as quais têm já muito pouca gente". ${ }^{18}$ Gandavo relatou que os portugueses desocuparam 
de índios as terras ao redor das povoações coloniais, entretanto, algumas aldeias permaneceram: "e assi ficou a terra desocupada de gentio ao longo das Povoações. Algumas aldêas destes índios ficarão todavia orredor dellas, que sam de paz, e amigos dos Portugueses que habitão estas Capitanias". ${ }^{19}$

Gabriel Soares de Souza mostrou a proximidade de aldeias de índios cristianizados, possivelmente de aldeias administradas pelos jesuítas, das vilas e fazendas, compondo um quadro único. Assinalou que na barra de São Vicente, na capitania de mesmo nome, penetrando rio acima

está a terra toda povoada de uma banda e da outra de fazendas mui frescas; e antes que cheguem à vila estão os engenhos dos Esquertes de Frades e o de José Adorno; e no rio está uma ilheta, além da qual, à mão direita está a vila de São Vicente, que é a cabeça desta capitania. Pelo sertão desta capitania nove léguas está a vila de São Paulo, onde geralmente se diz “o campo", na qual vila está um mosteiro dos padres da companhia, e de redor dela quatro ou cinco léguas estão quatro aldêas de índios forros cristãos, que os padres doutrinam. ${ }^{20}$

Fernão Cardim afirmou que essas povoações estavam bem perto de espaços transformados pelos colonos: "Partimos da aldêa do Espírito Santo para a de Santo Antonio, passamos alguns rios caudais em jangadas, fomos jantar em uma fazenda do collegio". ${ }^{21}$ Esse cronista visitou uma série de aldeias sob cuidado dos jesuítas e indicou que a sua estruturação espacial, pelo menos nesse primeiro século da colonização, não diferia de época em que estavam fora da administração dos padres. Continuavam as grandes tabas, quatro ou cinco rodeando um pátio central. Dentro de cada uma, várias famílias se abrigavam. Conforme descreveu:

Moravam os índios antes de sua conversão em aldêas, em umas ocas ou casas mui compridas, de duzentos, trezentos ou quatrocentos palmos, e cincoenta em largo, pouco mais ou menos fundadas sobre grandes esteios de madeiras, com as paredes de palha ou de taipa de mão, cobertas de pindoba, que é certo gênero de palma que veda bem água, e dura três ou quatro annos ... Este costume das casas guardam também agora depois de cristãos. Em cada oca destas há sempre um principal a que têm alguma maneira de obediencia ... Este exhorta a fazerem suas roças e mais serviços, etc. ${ }^{22}$

Sobre a origem das aldeias cuidadas pelos jesuítas, Cardim deixou de informar se a sua localização antecedia a submissão aos padres ou se estes ha- 
viam definido o sítio onde estavam instaladas. Dá a entender, porém, que num primeiro momento são resultado da vontade de cristianizar-se dos índios, ou seja, o antigo local continuou a ser utilizado. Fato é que não raro nos deparamos com a mudança na localização desses povoados, possivelmente de um sítio original, para outro definido pelos homens da Companhia de Jesus sob a alegação de que as terras encontravam-se esgotadas: "Estavam estes índios em ruim sitio, mal acommodados, e a igreja ia caindo: fez o padre que se mudassem à outra parte, o que fizeram com grande consolação sua". ${ }^{23}$

Fernão Cardim, que escreveu sobre suas viagens acontecidas entre 1583 e 1590, indicou que, ao final do século XVI, algumas áreas das quais os lusos não conseguiam se apossar, dada a resistência indígena, já começavam a se despovoar de seus habitantes tradicionais, abrindo frentes para a ocupação européia. Como escreve:

outra nação mora no Espírito Santo que chamão Tegmegminó: erão contrários dos Tupiniquins, mas já são poucos. Outra nação que se chama Tamuya, moradores do Rio de Janeiro, estes destruirão os Portugueses quando povoarão o Rio, e delles há muitos poucos, e alguns que há no sertão se chamão Ararape. ${ }^{24}$

Mas os lusos também encontravam muita dificuldade para se apossarem dos territórios indígenas em razão da aguerrida resistência. Gandavo afirmou que "Não há pela terra dentro povoações de portugueses por causa dos índios que não no consentem". ${ }^{25}$ Assim, parte da paisagem está em constante movimento, resultado de sucessivas e diferentes formas de ocupação.

Nada indica que o comércio entre os índios foi introduzido pelos europeus mercantilistas. Pelo contrário, essa exploração inicial dos produtos da terra por franceses e portugueses seria difícil de efetivar caso houvesse ausência de tráfico entre as populações indígenas. Voltamos a um ponto óbvio, aos índios que exploram os recursos naturais, e, embora o objetivo central fosse a sua própria manutenção, gerava-se alguma mercadoria. Enfim, quanto aos espaços não povoados por colonos, os europeus inseriram-se, num primeiro momento, numa dinâmica autóctone de exploração da terra, ainda que, em muitas regiões do litoral, já no primeiro século de colonização, tenham subvertido essas práticas colocando-as a seu serviço, quando passaram a escravizar os índios.

Alguns cronistas apresentam incongruências em suas descrições, justificadas pelos objetivos de suas obras. Pero Magalhães Gandavo, preocupado em acentuar os aspectos positivos da nova colônia, assim como Gabriel Soares de Souza, que indicou terras propícias para o povoamento europeu, co- 
mentaram sobre os índios, seus costumes e territórios. Exibiram uma terra povoada por vários grupos, alguns inimigos e outros amigos dos portugueses. Entretanto, não raro, deixaram de indicar claramente ao leitor, possivelmente aquele interessado em aplicar seu capital na colônia, que aquela terra "onde tudo dá" estava povoada pelos índios retratados. Os dois separam o relato sobre os índios da descrição das terras que ocupam e de seus recursos naturais. Tendo acabado de afirmar o barbarismo dos Aimoré, que ocupavam o litoral do Espírito Santo, Gandavo completa: "Esta terra he mui fertil e viçosa, toda coberta de altíssimos e frondosos arvoredos, permanece sempre a verdura nella inverno e verão ... As agoas que na terra se bebem são mui sadias e saborosas". ${ }^{26}$ Nessa paisagem natural, quase paradisíaca, que traça, não imaginamos os Aimoré, porque: "na terra nem têm casas nem povoações onde morem, vivem entre os matos como brutos animais". ${ }^{27}$ Contudo, a seqüência mostra que esses índios interferem na paisagem, explorando-a para construir suas ferramentas, perambulando por caminhos: "Não pelejam em campo nem têm ânimo para isso, põem-se entre o mato junto dalgum caminho ... Estes índios não vivem senão pela frecha, seu mantimento he caça, bichos e carne humana, fazem fogo debaixo do chão". ${ }^{28}$ Através dessa prática, dissociar o homem do espaço que ele habita, efetivada pela descrição dos aspectos naturais apartados da exposição das sociedades indígenas, criou-se a ilusão de que a terra estava vazia. Desconsideram-se os indícios de uma existência humana. Assim os índios foram barbarizados.

\section{CONCLUSÃO}

O que chama a atenção em todos esses cronistas é a recorrente referência aos índios, suas aldeias ao longo do litoral, algumas bem próximas à praia e outras mais no interior. A questão não é numérica, seria duvidoso pensar nesses textos como fontes objetivas de dados quantitativos. Caminha, que escreveu o primeiro relato sobre os nativos do território, confirma a improdutividade de tal intento. Ora se mostravam uns sessenta índios, segundo ele, ora eram quatrocentos. As mulheres eram muito poucas. Ele mesmo nos leva a questionar por que os índios se mostrariam todos. Independentemente da demografia indígena, Staden, Cardim e os outros cronistas identificam territórios indígenas.

A realidade que exibiram é muito diferente daquilo que Capistrano de Abreu e Caio Prado Júnior fixaram — e que a historiografia segue até hoje 
- como síntese desse período colonial. Esses historiadores partiram de viajantes do século XIX e de dados geográficos contemporâneos, do século XX, sobre a conformação física do território e de sua vegetação, como se nada, além do espaço ocupado pelos colonos, tivesse sofrido qualquer tipo de transformação. Além de pressuporem que o meio determinava de forma igual a ocupação colonial, assim como a indígena, acreditavam ser essa relação atemporal, ou seja, a-cultural. Partiram de uma concepção linear da história do povoamento do território, estabeleceram descrições em que as áreas que até a primeira metade do século XX eram fracamente ocupadas, assim o eram no século XVI ou XVII ou XVIII. Os vazios, os lapsos de povoamento do litoral atlântico Sul-americano parecem ser um fato que antecede e ultrapassa a chegada da esquadra de Cabral.

Os cronistas do século XVI e início do XVII nos levam a crer que ao longo desse período a costa da ilha do Maranhão ao rio da Prata foi uma zona fronteiriça, onde culturas e formas de organizações políticas, econômicas e sociais diversas e, portanto, paisagens diferentes, tanto se confrontavam como se mesclavam. Como aqueles que estiveram na América do Sul descreveram, tanto havia territórios marcados pelas aldeias, roças, acampamentos indígenas, matas e campos utilizados para a caça, recortados por trilhas que ligavam parentes, amigos e territórios inimigos — assim era o litoral entre Bertioga e a enseada de Mangaratiba descrito por Hans Staden - como existiam cidades e vilas coloniais e propriedades rurais refletindo enclaves europeus. Também se encontravam núcleos em que as moradias típicas indígenas quase se confundiam com as casas portuguesas, de tão próximas que se encontravam de algumas vilas as aldeias de índios cristianizados. Assim relatou Fernão Cardim, e dessa forma é o quadro montado pela historiografia paulista sobre o primeiro século da fundação de São Paulo de Piratininga. Alguns dos aldeamentos talvez já fossem mais expressão de um cotidiano europeu imposto que ameríndio, especialmente aqueles que foram transferidos de um local para outro. Enfim, paisagens diversas misturam-se no espaço, transformam-se em ritmos diversos e, nesse século, em sentidos muitas vezes diferentes.

No século XVI, conforme aqueles cronistas, nessas terras o cenário refletia tanto um movimento original deste continente, a expansão Tupi pela costa iniciada antes da chegada dos portugueses, como o movimento de invasão dos territórios indígenas pelos colonos vindos pelo oceano.

Os cronistas que traçaram as paisagens do litoral brasileiro no século XVI e início do XVII mostraram a instabilidade desses cenários. No século XIX, quando o continente foi visitado e esquadrinhado, coletado, estudado por 
viajantes e cientistas em início de carreira, as principais fontes de pesquisa de Capistrano de Abreu e de Caio Prado Júnior, parte dessa história pretérita da paisagem parecia não ter deixado vestígios, tanto que as áreas que haviam permanecido sob domínio e soberania dos índios foram concebidas como natureza virgem.

\section{NOTAS}

${ }^{1}$ Artigo apresentado no III Simpósio Latinoamericano y Caribeño de História Ambiental, III Encuentro Español de História Ambiental. Carmona, abril de 2006.

${ }^{2}$ PRADO JÚNIOR, Caio. Formação do Brasil contemporâneo. 14.ed. São Paulo: Brasiliense, 1976, p.23.

${ }^{3}$ Neste artigo utilizaremos a denominação dos grupos indígenas empregada pelos cronistas.

${ }^{4}$ PEREIRA, Paulo Roberto (Org.) Os três únicos testemunhos do descobrimento do Brasil. Carta de Pero Vaz de Caminha. Carta de Mestre João Faras. Relação do Piloto Anônimo. Rio de Janeiro: Lacerda, 1999, p.58.

${ }^{5}$ PEREIRA, Paulo Roberto, cit., p.50.

${ }^{6}$ Ibidem, p.58.

${ }^{7}$ Ibidem, p.50.

${ }^{8}$ Francisco de Assis Barbosa apresenta várias notas explicativas e comentários ao livro de Hans Staden, lembrando que o alemão refere-se a duas Ubatubas visitadas por ele. Ambas entre Bertioga e Rio de Janeiro. A partir de leituras de outros especialistas, conclui que a Ubatuba onde Staden ficou prisioneiro situava-se no litoral carioca. Ver: STADEN, Hans. Duas viagens ao Brasil. Belo Horizonte: Itatiaia; São Paulo: Edusp, 1974, nota 108.

${ }^{9}$ STADEN, Hans, cit., p.87.

${ }^{10}$ D'ABBEVILLE, Claude. História da missão dos padres capuchinhos na ilha do Maranhão e terras circunvizinhas. Belo Horizonte: Itatiaia; São Paulo: Edusp, 1975. p.139.

${ }^{11}$ STATEN, Hans, cit., p.87.

${ }^{12}$ Ibidem, p.154.

${ }^{13}$ CARDIM, Fernão. Tratados da terra e gente do Brasil. Belo Horizonte: Itatiaia; São Paulo: Edusp, 1980. p.106.

${ }^{14}$ STADEN, Hans, cit., p.125.

${ }^{15}$ Ibidem, p. 104 . 
${ }^{16}$ SOUZA, Gabriel Soares de. Tratado descritivo do Brasil em 1587. Belo Horizonte: Itatiaia, 2001. p.62.

${ }^{17}$ CARDIM, Fernão, cit., p.103, 105.

${ }^{18}$ SOUZA, Gabriel Soares de, cit., p.62.

${ }^{19}$ GANDAVO, Pero Magalhães. Tratado da terra do Brasil. História da Província de Santa Cruz. Belo Horizonte: Itatiaia; São Paulo: Edusp, 1980. p.85.

${ }^{20}$ SOUZA, Gabriel Soares de, cit., p.86-7.

${ }^{21}$ CARDIM, Fernão, cit., p.154.

${ }^{22}$ Ibidem, p. 152.

${ }^{23}$ Ibidem, p. 167.

${ }^{24}$ Ibidem, p.102-3.

${ }^{25}$ GANDAVO, Pero Magalhães, cit., p.23.

${ }^{26}$ Ibidem, p.46.

${ }^{27}$ Ibidem, p.34.

${ }^{28}$ Ibidem, p.34. 